sure in the atmosphere are created by currents of air associated with straight isobars, in which the velocity is not of the right amount to produce a balance between pressure gradient and the deviating force due to the earth's rotation, and that the effect of gravitational forces on masses of air, the entropy of which differs from that of their environment, can develop a column of low pressure.

\section{The People's Cinema University}

A IEADING recommendation of the Commission on Educational and Cultural Films which was set up in 1929 was the establishment of a National Film Institute (see Nature for June 18, p. 911). One is interested, therefore to observe the scheme evolved by Sir James Marchant and Sir Oswald Stoll for the establishment in London of the People's Cinema University. The university, it is stated, would consist of a central building, from which lecture halls equipped with sound-film installations for the regular exhibition of films would radiate. In the central dome there would be a Zeiss planetarium. There would also be reading rooms, offices, etc., available for film patrons and societies. All these features are combined in an imposing general design prepared by Sir Giles Gilbert Scott. The films would be made in co-operation with an expert educational board to meet the requirements of teachers and scholars, and would be distributed and collected by motor cinema vans throughout the country. Projectors also would be supplied to schools, churches, and institutions. In his broadcast address and in letters to the Times, Sir James has directed attention to useful educational work already accom. plished. The catalogues issued by Visual Education, Ltd., indeed, list quite an impressive series of educational and cultural films. Sir James believes, therefore, that the time is ripe for such a venture as the People's Cinema University, which, in its own sphere, would attempt work resembling that of the B.B.C.

\section{Change in Colour of Birds due to Exposure}

Mr. P. J. Norman, in Cage Birds for Aug. 6 (p. 70), cites a remarkable case in which a black-headed variety of the budgerigar, after being turned out into an outdoor aviary provided with a 'flight' or net. roofed annexe, so that the birds were exposed to rain if they wished it, has resumed the normal yellow colouring of the head. The breeder of this bird, it seems, has stated that all of its nest-fellows were also black-headed, and that these had retained the black head through a moult. The family had been bred indoors, in a cage, and it is suggested that in the case of the bird which reverted, the exposure to open air and rain in its new quarters had brought about the return to normal plumage. It would, however, be well worth while to see whether outdoor treatment would operate in this way with the rest of the brood; or, if they be still kept indoors, whether they will produce black-headed young. It may be noted here that of the first two specimens of the rare East Asiatic Derbyan parrakeet the London Zoological Society possessed, one became black-headed and afterwards re- verted to normal, while its companion did not change, though both lived in the same cage indoors in the old Parrot House.

\section{Helminthological Abstracts}

ONE of the first fruits of the various agricultural bureaux formed by the Imperial Agricultural Research Conference has been the establishment of a number of abstracting journals, the latest of which to appear being Helminthological Abstracts, under the editorship of Prof. R. T. Leiper. This new journal, which is issued as a supplement to the Journal of Helminthology, differs in several important respects from the others. Papers are arranged by journals, not by subjects, and each abstract is printed so that the first sentence is in effect an extended title ; the remainder is a succinct abstract of the chief results obtained by the authors. The Abstracts will be issued in five parts each year, the first of these being in April. This will enable a single volume to cover the entire literature for the calendar year, so that, in addition to keeping the current literature before the reader, it will when bound form a complete summary of the year's work. It is priced at 16s. 6d. a volume, post paid, and is obtainable from the Institute of Agricultural Parasitology, St. Albans. Another publication from the same Bureau is the "Bibliography of Helminthology" for the year 1930 (6s.). This volume contains references to more than 900 titles in 346 different journals. These titles are arranged by journals, with an adequate authors' index. The volume has the same format as the Abstracts, and although issued separately could be bound with the completed volumes to form an invaluable index to the journals abstracted and the authors of the papers.

\section{Prof. Richard Willstätter}

Die Naturwissenschaften for Aug. 12 is a special issue in honour of Prof. Richard Willstätter's sixtieth birthday. The memoir contains a series of articles by experts upon the fruitful results of his memorable researches in organic chemistry. Prof. F. Haber refers to the successful campaigns which Willstätter has conducted in different branches of biochemistry, for the exceptional skill which he displayed in elucidating chemical structures was principally concentrated upon problems closely related to living matter. Prof. Pummerer reviews the results of forty years of strenuous endeavour. First comes a masterly series of papers upon alkaloids, culminating in the synthesis of tropin and cocaine; then for a while aromatic structures claim attention, particularly quinone-imines, aniline black, and cyclo-octa-tetraene. But Willstätter's interest in plant life led him to the study of the compounds to which plants owe their distinctive colours. Thus chlorophyll, carotene, and the anthocyanins were investigated in turn, and the success attained in each of these branches led him to the further problem of assimilation by plants. This involved the study of enzymes, which has yielded some astonishing results in recent years. Prof. L. Zechmeister describes the main lines of Willstätter's work on carotinoids and the important hydrocarbon carotene, which has come into prominence on account

No. 3278, VoL. 130] 
of its relation to chlorophyll and to vitamins. Prof. R. Robinson discusses in some detail the structures of anthocyanins, the red and blue colouring matter of flowers. Prof. R. Kuhn refers to the influence of Willstätter's work on the development of the theory of heteropolar rings, and Dr. Waldschmidt-Leitz describes the process of resolution of enzyme mixtures from the pancreas and from yeast by a method of selective adsorption. The concluding article upon chlorophyll and its derivatives is by Prof. A. Stoll and Dr. E. Wiedemann.

\section{A New Periodical for Chemical Physics}

As a part of its comprehensive programme of physics publications, the recently formed American Institute of Physics (see Nature for Aug. 6, p. 199) announces that it will shortly begin a new publication to be called the Journal of Chemical Physics. The first number will be issued in January 1933. Primary among the circumstances which have led the Institute to undertake the new publication is the increasing number of articles on physical chemistry which have distinct bias on the physical side. These have not found a suitable outlet in any journal now in existence, being perhaps too mathematical for the Journal of Physical Chemistry, too physical for the Journal of the American Chemical Society, or too chemical for the Physical Review. Inquiries or suggestions concerning the new journal should be addressed either to Dr. Harold C. Urey, Department of Chemistry, Columbia University, or to the American Institute of Physics, 11 East 38th Street, New York.

\section{Irrigation in India}

THE progress of irrigation and the use of the available water are surveyed in the "Triennial Review of Irrigation in India, 1927-30" (Simla: Government Press, 2s. 6d.). It would appear that the monsoon of 1927 was almost normal in its time and rainfall except for a slight deficit. In 1928 there was a marked deficiency in the north-west, and in 1929 the principal departure from the average was an excess of 100 per cent in the rainfall of the North-West Province and Sind. During the three years under review, the average area irrigated by Government works in British India was 29,954,000 acres, an advance of more than two million acres on the corresponding figure for the previous triennium. The chief increase was in the Punjab valley, owing to the development on the Sutlej valley canals. It is noticeable that, of the total sown area, 12.7 per cent was irrigated. Among the most important projects now in hand are the Sukkur Barrage and canals in Sind, the Sarda canal and a hydro-electric power scheme on the Ganges canal in the United Provinces, and the Sutlej valley project in the Punjab. The problems of water supply in Baluchistan are being considered in the hope of improving the very poor irrigation facilities.

\section{Commonwealth of Australia Yearbook}

THE Yearbook of the Commonwealth of Australia for 1931 contains a mass of descriptive and statistical matter, of which much is of considerable scientific value. The prevalent demand for economy has curtailed to some extent the size of the volume, but there is little evidence of its usefulness being impaired. The figures dealing with agricultural production are particularly full, vital statistics are given much space, and there is a long article, accompanied by distributional maps, on the climate and meteorology of Australia.

\section{Announcements}

Prof. R. Rugales Gates will deliver three De Lamar lectures at the Johns Hopkins University during the week beginning Oct. 24, on "The Principles of Heredity in Man, and their Application to Society".

Ir is announced in Science that Prof. Rudolph W. Ladenburg, of the Kaiser Wilhelm Institut für physikalische Chemie und Elektrochemie, has been appointed to the Cyrus Fogg Brackett research professorship at Princeton University, in physics.

THe Society for Cultural Relations with Soviet Russia is considering the possibility of arranging a tour of scientific institutions in Russia, to leave London on Sept. 10. It is proposed to arrange for parties of British scientific workers engaged in physical, biological, and medical research, and for engineers, chemists, and anthropologists, to visit the corresponding institutions in Russia, and to meet Russian workers engaged in similar research. The total cost of the tour is about $£ 35$ inclusive, the time being approximately one month from departure to return to London. Further particulars and application forms may be obtained from the Secretary, S.C.R., 1 Montague Street, London, W.C.I.

Messrs. W. and G. Foyle, Ltd., of 119-125 Charing Cross Road, W.C.2, have recently published a new catalogue of new and second-hand books on technical subjects and applied sciences. More than 450 subjects are represented. About three thousand books are catalogued, and the list should prove a source of help. The majority of the standard works are available, many of them being obtainable second-hand as well as new.

Applicatrons are invited for the following appointments, on or before the dates mentioned:-A headmaster for the Netherton Farm School, near Morpeth, Northumberland-The Secretary, 18 City Road, New. castle-on-Tyne (Sept. 3). An assistant conservator of forests in the Department of Agriculture and Forests, Sudan Government-The Controller, Sudan Government London Office, Wellington House, Buckingham Gate, S.W.1 (Sept. 5). A professor of zoology at the University of Bristol-The Secretary and Registrar (Oct. 1). A resident tutor of chemistry, rural science, and school hygiene at the Winchester Diocesan Training College-The Principal. A headmaster of the Incorporated Thames Nautical Training College, H.M.S. Worcester-The Secretary, Ingress Abbey, Greenhithe, Kent. An assistant (woman), with analytical experience in organic and inorganic work, at the Air Ministry, Kidbrooke-The Secretary, (I.G.), Air Ministry, W.C.2.

$$
\text { No. 3278, VoL. 130] }
$$

